\title{
ПРИКЛАДНА ЕКОНОМІКА
}

UDC 331.5-057.875:616-036.21](438)

DOI: 10.26565/2311-2379-2020-98-09

\author{
Anna Stankiewicz-Mróz \\ Ph.D.(Economics), Associate Professor \\ Lodz University of Technology \\ 116 Żeromskiego Str., 90-924, Lodz, Poland \\ E-mail: anna.stankiewicz-mroz@p.lodz.pl, ORCID: https://orcid.org/0000-0003-4778-6672 \\ Natalia Jarominek \\ student \\ Lodz University of Technology \\ 116 Żeromskiego Str., 90-924, Lodz, Poland \\ E-mail: 224953@edu.p.lodz.pl
}

EMPLOYMENT OF POLISH STUDENTS DURING THE COVID-19 PANDEMIC

Rapidly increasing cost of living in Poland is reflected in a high professional activity of students. Currently, the majority of the students on the Polish labor market is employed on the basis of civil law agreements. Civil agreements do not guarantee a sense of security and they are attractive primarily for employers. The civil contract allows employers to reduce employment costs. Their attractiveness for the employees is connected with the flexibility of working time. The advantage for the students of performing work under civil agreements is that it allows them to combine study with work. But they prefer part-time work. Civil contracts are often pejoratively referred to as "junk contracts", because they do not protect employee's interests. This is particularly observed during a crisis (like in the current situation connected with the COVID-19 pandemic). The aim of this paper is to present the results of the analysis of the situation of working students and the possibility of its impact on anti-crisis actions taken by the government in order to protect society against the effects of the pandemic. The research was conducted among students of Lodz University of Technology (Poland) in the first quarter of 2020, with the use of an on-line survey. The study assumes that the preference of employers concerning the employment of students based on atypical forms results in the lack of protection in new and unpredictable situations such as the current one. The article determines students level of knowledge about the available forms of assistance under the AntiCrisis Shield 2.0. The research shows that very few respondents are aware of the accessible assistance guaranteed by the Act.

Keywords: atypical forms of employment, professional work of students, Anti-Crisis Shield 2.0.

JEL Classification: E24, J01, J21, J62.

Introduction. In 2018, according to the data of the Ministry of Science and Higher Education and the Central Statistical Office, a bit more than one million two hundred thousand persons studied in Poland, and average student maintenance costs were about 2.122,99 PLN (Raport «Portfel Studenta», 2019). Higher living costs translate into the professional activity of students. According to the date from the report of the Polish Business Council "Student at work in 2019», approximately $82 \%$ of students work professionally. Currently, the majority of the students on the Polish labor market are employed on the basis of contracts of mandate. Their attractiveness is connected with the flexibility of working time. Thanks to this form of employment, students can study and work without hindrance. It enables to gain experience, as well as generate additional income, because the share of their own earnings in the student's monthly budget in Poland is over $54 \%$ (Raport: Student w pracy 2019, 2019).

The period of an epidemic status in Poland is a difficult time, especially for people, who work on the basis of contracts of mandate, because in the current situation on the labor market, students do not have any privileges during the reduction of job positions and they are often left without means of a livelihood. Many industries (mainly industries, in which students were usually employed) cannot operate due to restrictions resulting from the state of the pandemic. This also results in a lack of orders and income opportunities. The goal of this article is to present the results of the research

\footnotetext{
${ }^{\bullet}$ Stankiewicz-Mróz A., Jarominek N., 2020
} 
aimed at identification of the situation of working students during the pandemic. The research included students of the Lodz University of Technology, who are employed on the basis of various forms of employment.

1. Flexible forms of employing students. The research conducted in 2017 showed that more and more people in Poland declared their willingness to work differently than in the traditional model described by the rigid working time (i.e. «from-to»). According to the report entitled «How do Poles like to work?»(Embassy, 2018) as many as 42\% of respondents support a modern flexible model of work. Young employees dominate in a group of people interested in flexibility of work (Addor, 2011). However, there is a large group of employees characterized by rather "forced" flexibility. Flexibility, which is connected with the use (by employers) of atypical forms of employment, is forced by the turbulence of the environment (Report «Generational changes on the labor market-XYZ», 2018). It enables enterprises to implement in practice the concept of J. Atkinson's flexible organization (Atkinson, 1984) or Ch. Handy's shamrock organization (Handy, 1993). These concepts assume flexibility in numerical, time and functional dimensions. Based on these concepts, flexibility enables an enterprise to quickly relativize the size of employment, as well as working time and competence of personnel to the changing conditions of the labor market. Flexibility treated in this way is related to the phenomenon of labor market segmentation within the enterprise and results in a reduced sense of employees' security, a lower level of investment in human capital development and higher fluctuation rates. In relation to flexibility understood in this way, terms "flexible exploitation" or "flexploitation" are sometimes used (Gray, 2004). Civil law contracts are often pejoratively referred to as "junk contracts". In some industries (e.g. gastronomy, services), many employees are doomed to work on the basis of civil law contracts. They are derived of significant employee rights. This is particularly observed during a crisis (like in the current situation connected with the COVID-19 pandemic). According to the data of the Central Statistical Office, in 2018, 1.3 million people were employed on the basis of civil law contracts (GUS). In terms of the number of persons providing work in the discussed forms, Poland ranks second in Europe after Spain. Flexible forms of work are primarily interesting for students, because these forms enable reconciliation of professional activity and education (Seemiller, Grace, 2016). For students, work is also the fulfillment of material aspirations that are related to the need to possess. Consequently, the work enables to achieve appropriate material status. According to the report entitled Gen Z and Millennials collide at work (Report «Gen Z and Millennials collide at work»,2016), for almost every fifth representative of this generation, offering a flexible job will translate into the final working decision (for comparison: trainings and development opportunities were indicated only by $15 \%$ of respondents). The research conducted by J. Gajda (Gajda, 2017) among 186 students of the Wroclaw University of Economics indicated that $92 \%$ of surveyed representatives of the $Z$ generation underline the importance of facilities that balance work and personal life. The research carried out by $A$. Bohdziewicz (Bohdziewicz, 2016) led to a similar conclusion. The evaluation of the attractiveness of employment on the basis of civil law contracts is affected by the situation of a sudden crisis, the consequence of which is (inter alia) the need to limit professional activity.

2. Protective measures taken by the government as a part of the Anti-Crisis Shield program. In order to ensure protection against the effects of the crisis, the Act "on special support instruments in connection with the spread of SARS-CoV-2 virus" (Dziennik Ustaw poz.695, 2020) (colloquially known as Shield 2.0) was introduced on 16 April 2020. The Shield is a package of solutions prepared by the government aimed to protect the Polish state and citizens against the pandemic crisis. It is based on the following pillars:

- Protection of jobs and safety of employees;

- Financing of entrepreneurs;

- Health care;

- Strengthening the financial system;

- Public investments.

From the point of view of this study, regulations on the protection of jobs and safety of employees, working on the basis of civil law contracts, are relevant. If it is not possible to provide work, such persons can take advantage of the idle time pay. In Article 15 section 5 point 1 , there is a provision that "a person employed on the basis of a civil law contract is entitled to the idle time pay if the civil law contract was concluded before February, 12020 ". The idle time pay amounts to $80 \%$ of 
the minimum remuneration. It is important (from the point of view of using this protection) that the employee must receive at least 1.300,00 PLN (gross) from all contracts of mandate during one month - i.e. $50 \%$ of minimum remuneration. If a person employed on the basis of a contract of mandate only occasionally earns extra money, he or she is not entitled to the idle time pay. The application for the payment of the idle time pay is made through the employer. An employee (interested in payment of this benefit) cannot make such an application. results.

3. Situation of working students during the COVID-19 pandemic in the light of research

Research methodology. The research was conducted among students of the Lodz University of Technology in the first quarter of 2020 with the use of an on-line survey containing (primarily) closed questions. Several questions were open. The survey included answers of anonymous respondents.

The research involved 76 students of the Lodz University of Technology. They were randomly selected using the criterion of availability of respondents. In this group, 55 persons declared professional activity. The goal of the research was to identify the professional situation of students during the COVID-19 pandemic. In the examined group, 55 persons (representing $72 \%$ of respondents) were working professionally before the pandemic. This group was a subject of the analysis in the further part of the examination.

An important issue from the point of view of the research problem was to identify a legal form of our respondents. The structure of the obtained answers was presented in Figure 1.

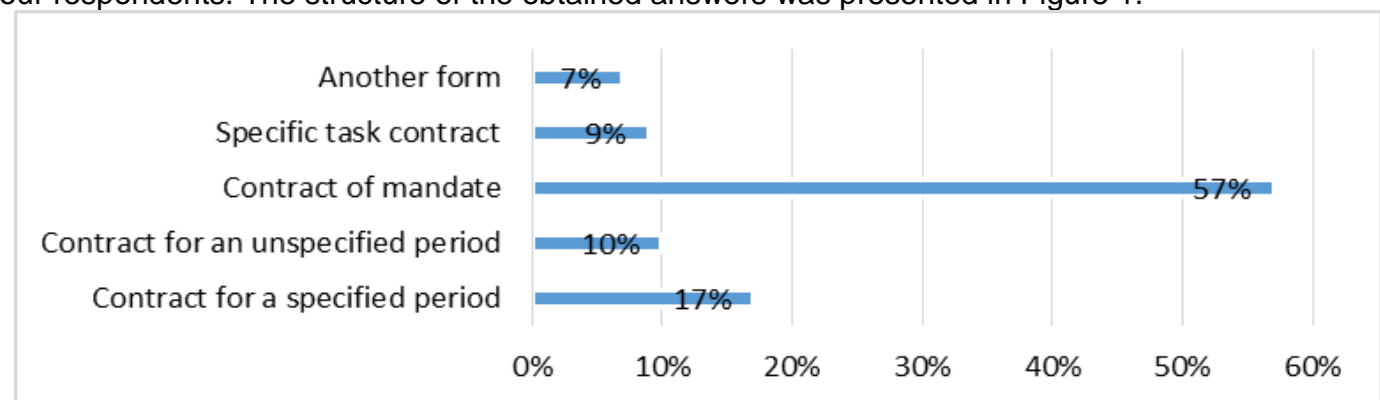

Source: own research

Fig.1. Structure of respondents in terms of legal form of employment

The research showed that $57 \%$ of surveyed students work on the basis of a contract of mandate, $17 \%$ of students work on a contract for a specified period, $10 \%$ - on a contract for an unspecified period and $9 \%$ - on a specific task contract. These results indicate that almost three quarters of respondents are employed on the basis of the so-called "junk contracts" (characterized by a minimum protection of persons). In Poland, more than 1.2 million employees worked on the basis of civil law contracts (GUS). Such forms of employment are alternatively referred to as flexible forms. As research shows, they are a form of coping with uncertainly of the environment by employers (Stankiewicz-Mróz, 2020). Flexible employment can take various forms. Therefore, the research identified forms that are particularly popular among students. The obtained results were presented in Figure 2.

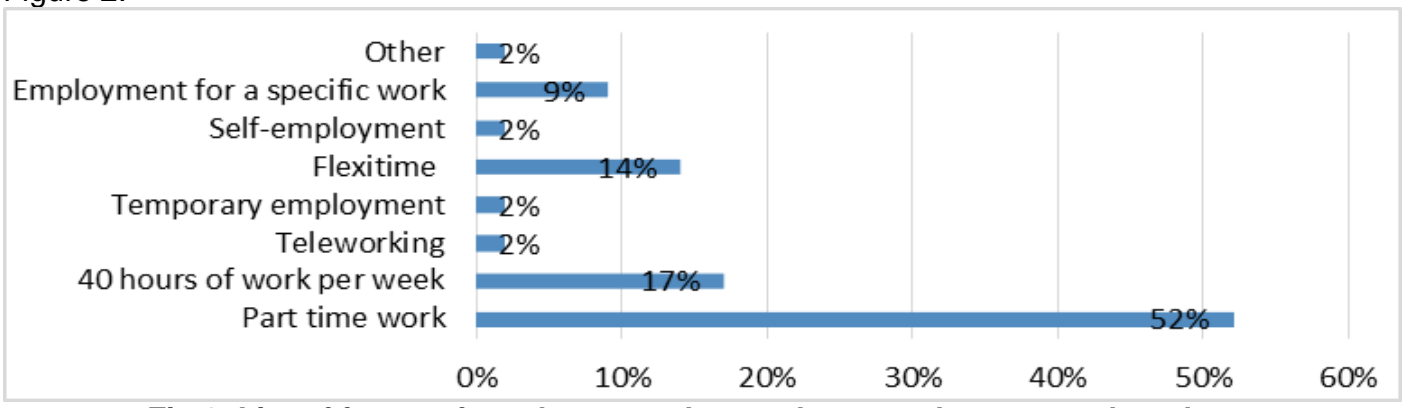

Fig.2. List of forms of employment observed among the surveyed students

Source: own research 
The research showed that the majority of respondents provided part time work (52\%). Full time work (40 hours per week) is performed by $17 \%$ of students, $14 \%$ of respondents have flexible working time, employment for a specific work is declared by $9 \%$ of respondents, and $2 \%$ of students work on the basis of teleworking, temporary work, self-employment or other forms.

The next part of the analysis focused on the duration of students' employment before the pandemic. This is important in the context of assistance measures for employees within the framework of the Shield 2.0. The results of the study show that $91 \%$ of respondents worked for over 30 days, while $9 \%$ of respondents for less than 30 days. The pandemic resulted in a significant reduction in available work, as well as its form. The quarantine announced by the government resulted in the closing of hotels, restaurants, hairdressers, beauty salons, dental offices, shops and many factories. Additionally, the introduced restrictions caused that employers were forced to reorganize the space for employees. Many organizations were switched to the remote work system. Employment data provided by the Central Statistical Office in March 2020 confirmed that due to the outbreak of the coronavirus pandemic, the labor market slowed down dramatically - compared to February 2020, the number of employees decreased by approx. 34.2 thousand people (GUS).The GUS's data does not include temporary employees or employees working on the basis of civil law contracts. Therefore, the real decline in employment in March could be much larger than the decline presented in official statistics. Specialists say about approx. 100 thousand people (Koronawirus a rynek pracy, 2020). In the context of the presented situation, it is important to determine the situation of the examined students. Therefore, another question directed to respondents examines the scope of performed work despite the pandemic. The research showed that only $35 \%$ of students are still working despite the pandemic. The majority of them found themselves in a situation that prevents the performance of work. The next questions attempted to determine why $65 \%$ of students are unemployed. This question was limited to the indication of the main reasons for the loss of work by employees. They were divided into the following options: closing the workplace, lack of orders for company and dismissal due to less work to do. The majority of people, who currently do not work, were employed on the basis of contracts of mandate. The above-mentioned data was presented in Figure 3.

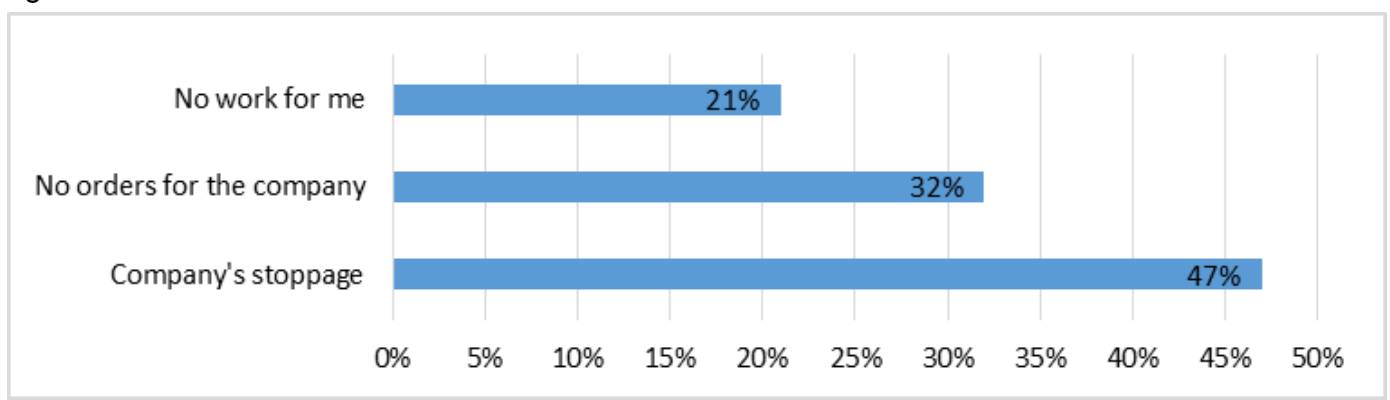

Fig.3. Structure of respondents' answers - why are they not working

Source: own research

The previous research show that the situation raises large concerns connected with the functioning of the labor market. The research by the Economic Situation Monitoring Center (ESMC) presented that in April 2020 about $88 \%$ of surveyed companies expect a reduction in employment. The average declared reduction in employment (regardless of the company's size) is $15.5 \%$. In the case of micro-enterprises, it is $16.6 \%$, and medium-sized enterprises - 15.3\%. Large enterprises forecast the smallest reduction in employment (average: 7\%) (March lavina of release, 2020). The next question attempted to determine whether the form in which respondents currently provide work has changed. For this reason, the following question was asked: «Has your form of work changed during the pandemic?».

On the basis of the obtained answers, we indicate that in the case of 10 persons, who work despite the pandemic, the form of work has changed. The above-mentioned respondents indicated remote work as a different form. 
The next question concerned the working time. This question was aimed to diagnose the problem of how a pandemic state in our country limits the working time for students or whether a pandemic state has an impact on the demand for work usually provided by students. The obtained results show that 9 respondents work shorter than before the pandemic, while 7 persons (37\%) work for the same period of time as before the pandemic. Students, who declared shorter work during the pandemic, indicate that the reason for this situation (first of all) is the lack of work to do or the allocation of responsibilities to more people. It was also important to examine whether the earnings of currently working respondents changed during the pandemic. When analyzing the obtained result (concerning the change in remuneration of respondents during the pandemic), it can be stated that earnings have not changed for $55 \%$ of respondents. This shows that companies do not decide to reduce remuneration as often as it is assumed. The research also identified current problems and concerns of respondents related to work. They were divided into four groups, i.e. technical problems, commuting, lack of security measure and lack of information about the employer's intentions (Figure 4).

Lack of information from employers

Lack of security measures

No possibility of commuting

Technical problems

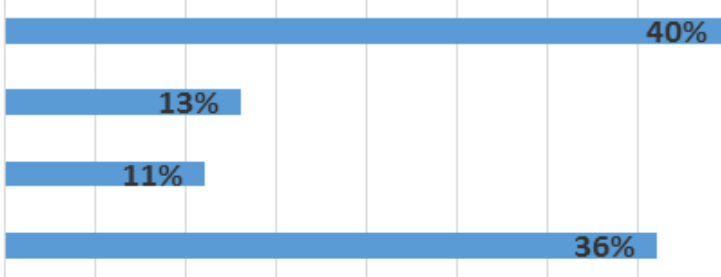

$\begin{array}{llllllllll}0 \% & 5 \% & 10 \% & 15 \% & 20 \% & 25 \% & 30 \% & 35 \% & 40 \% & 45 \%\end{array}$

Fig.4. List of respondents' problems and concerns that are related to their current job.

Source: own research

The majority of respondents (40\%) indicate a lack of information from employers, which is connected with a lack of certainly about further employment. $36 \%$ of people have technical problems with work - this mainly applies to respondents, who work remotely. They complain about freezing computer, malfunctioning servers and lack of adequate equipment. Due to restrictions concerning public transport, $11 \%$ of respondents have problems with commuting. This is due to the change in the organization of public transport and the restrictions that must be observed in public transport. $13 \%$ of respondents do not have appropriate security measures and workstations adapted to the guidelines presented in Ordinances of the Ministry of Health.

The last examined aspect related to the work of students during the pandemic was forms of financial assistance accessible for respondents in connection with the pandemic. The aim of this question is to check the situation of students, who are unable to carry out their work or carry out work on a smaller scale. The results are indicated in Figure 5.

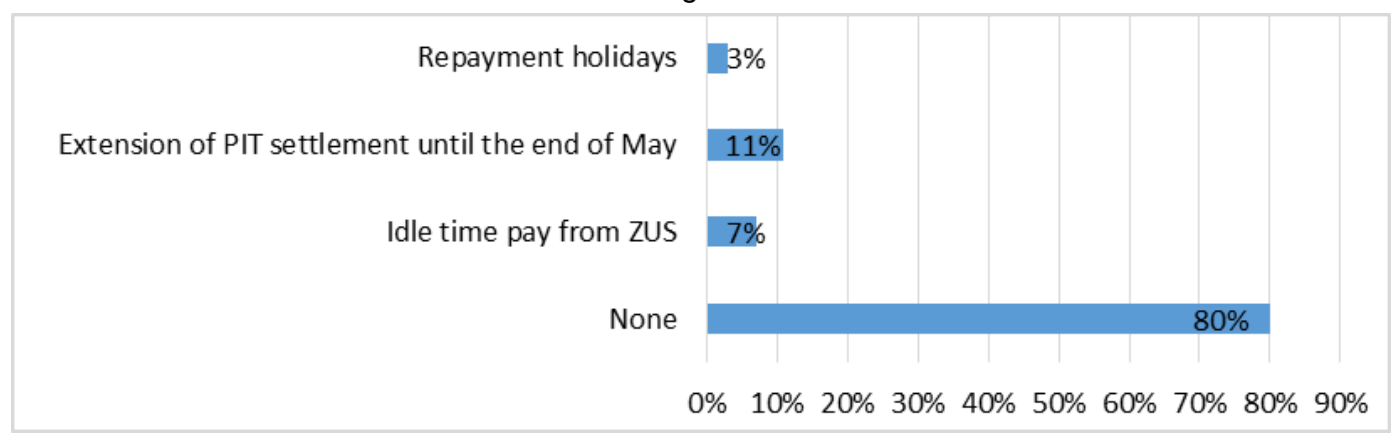

Fig.5. Structure of respondents, who are entitled to financial assistance due to the pandemic Source: own research 
The research showed that the vast majority of respondents $(80 \%)$ believe that they are not entitled to any assistance due to the pandemic. This is often associated with forms and conditions of employment, which were not covered by the Anti-Crisis Shield 2.0 and 3.0, and sometimes due to the lack of knowledge how to get assistance.

Conclusion. The study presented that the majority of students are employed on the basis of "junk contracts" - i.e. a contract of mandate or a specific task contract. They usually do not work on a full-time basis and they are employed for more than 30 days before the pandemic. The realized form of employment of students caused that during the crisis the examined group was unable to perform work. Due to the situation on the labor market and remote classes, they have limited opportunities to find a new job. This situation is related to the fact that students most often worked in restaurants, hotels, gyms or they worked as additional employees in a company. The majority of these companies suspended their business activity or they have a stoppage. Furthermore, still operating companies have less work, which results in a lack of work for people employed on the basis of contracts of mandate. First of all, employers must take care of employees, who are employed under an employment contract. Employees usually have a shorter working time due to the division of responsibilities among a larger number of employees. People, whose form of work has changed into remote work, are in a comfortable situation, but they over often struggle with technical problems resulting from this form of work. Contrary to the initial forecasts, earnings of people employed during the pandemic crisis have not changed. However, employees do not have basic information and there are doubts and anxiety related to the impact of the pandemic on the financial situation. Nobody informs employees about actions planned in their company in relation to the pandemic. Moreover, the research shows that very few respondents are aware of the accessible assistance guaranteed by the Act commonly referred to as the Anti-Crisis Shield 2.0 and the Anti-Crisis Shield 3.0.

1. Raport «Portfel Studenta». 2019. URL: https://zbp.pl/getmedia/db30e431-257b-4b47-9942e8164e844966/PortfelStudenta2019.

2. Raport: Student w pracy 2019. 2019. URL: https://hrpolska.pl/rynek-pracy/badania/raport-student-wpracy-2019.

3. Embassy, B. Raport «Jak Polacy lubią pracować». 2018. URL:https://be.prowly.com/13951-raportbrain-embassy-jak-polacy-lubia-pracowac.

4. Addor, M., L. Generation Z: What is the Future of Stakeholder Engagement? 2011. URL: https://iei.ncsu.edu/wp content/uploads/2013/01/GenZStakeholders2.pdf.2020

5. Report «Generational changes on the labor market-XYZ». 2018. Centrum Innowacji ProLearning. URL: www.prolearning.pl.

6. Atkinson J. Manpower strategies for flexible organizations. Personnel Management. 1984. Vol.15(8). P. $28-31$.

7. Handy Ch. Understanding Organizations. New York:Oxford University Press, 1993. 445 p.

8. Gray A. Unsocial Europe. Social Protection or Flexploitation? London: Pluto Press, 2004. 240 p.

9. Główny Urząd Statystyczny (GUS). URL:https://stat.gov.pl/.

10. Seemiller C., Grace M. Generation Z Goes to College, San Francisco: Wiley, 2016. 286 p.

11. Report «Gen Z and Millennials collide at work». 2016. URL: https://cdn2.hubspot.net/hubfs/409577/PreTeam\%20Drive\%20PDFs/Gen Z Millennials Collide Report Dec 2016.pdf.

12. Gajda J. Oczekiwania przedstawicieli pokolenia $Z$ wobec pracy zawodowej i pracodawcy. Prace naukowe uniwersytetu ekonomicznego we Wrocławiu. 2017. №491. P. 158-171. DOI: 10.15611/pn.2017.491.15.

13. Bohdziewicz P. Kotwice kariery zawodowej przedstawicieli pokolenia Z: kilka wniosków dla zarządzania najmłodszą generacją pracowników. Zarządzanie Zasobami Ludzkimi. 2016. Nr 6. S. 57-74

14. Dziennik Ustaw. 2020. Act „O szczególnych instrumentach wsparcia w związku z rozprzestrzenianiem się wirusa SARS-CoV-2", poz.695. URL: https://orka.sejm.gov.pl/proc9.nsf/ustawy/324 u.htm.

15. Stankiewicz-Mróz A. Perception of work flexibility among students as representatives of generation Z and employers from the SME sector. Human Resources Management. 2020. No 1(132). P. 49-63. DOI: $10.5604 / 01.3001 .0013 .8778$.

16. Koronawirus a rynek pracy. 2020. URL: https://innpoland.pl/159181,koronawirus-a-rynek-pracy.

17. Marcowa lawina zwolnień zmiotła «Tarcze antykryzysowe». 2020.

URL: https://pracodawcyrp.pl/aktualnosci-koronawirus/marcowa-lawina-zwolnien-zmiotla-tarcze-antykryzysowe. 


\section{References}

1. Report «Student's Wallett».(2019). Retrieved from https://zbp.pl/getmedia/db30e431-257b-4b47-9942e8164e844966/PortfelStudenta2019. (in Polish)

2. Report «Student at work 2019» (2020). Retrieved from https://hrpolska.pl/rynek-pracy/badania/raportstudent-w-pracy-2019. (in Polish)

3. Embassy, B. (2018). Report «How do Poles like to work». Retrieved from https://be.prowly.com/13951raport-brain-embassy-jak-polacy-lubia-pracowac. (in Polish)

4. Addor, M. L. (2011).Generation Z: What is the Future of Stakeholder Engagement? Retrieved from https://iei.ncsu.edu/wp content/uploads/2013/01/GenZStakeholders2.pdf

5. Report "Generational changes on the labor market-XYZ» (2018). Centrum Innowacji ProLearning. Retrieved from www.prolearning.pl.

6. Atkinson, J. (1984). Manpower strategies for flexible organizations. Personnel Management, 15(8), 28-31.

7. Handy, Ch. (1993). Understanding Organizations. New York: Oxford University Press.

8. Gray, A. (2004). Unsocial Europe. Social Protection or Flexploitation? London: Pluto Press.

9. Central Statistical Office. (2019). Retrieved from https://stat.gov.pl/.

10. Seemiller, C., Grace, M. (2016). Generation Z Goes to College. San Francisco: Wiley.

11. Report «Gen Z and Millennials collide at work» (2016). Retrieved from https://cdn2.hubspot.net/hubfs/409577/Pre-Team\%20Drive\%20PDFs/Gen Z Millennials Collide Report Dec 2016.pdf.

12. Gajda, J. (2017). Expectations of representatives of generation $Z$ towards work and employers. Research papers of Wrocław University of economics, 491, 158-171. doi: 10.15611/pn.2017.491.15.(in Polish)

13. Bohdziewicz, P. (2016). Career anchors of representatives of the $Z$ generation: several applications for managing the youngest generation of employees. Human Resource Management, 6, 57-74. (in Polish)

14. Journal of Laws (2020). Act «On specific support instruments in connection with the spread of SARSCoV-2 virus», item 695. Retrieved from https://orka.seim.gov.pl/proc9.nsf/ustawy/324 u.htm. (in Polish)

15. Stankiewicz-Mróz, A. (2020). Perception of work flexibility among students as representatives of generation $Z$ and employers from the SME sector. Human Resources Management, 1(132), 49-63. doi: $10.5604 / 01.3001 .0013 .8778$.

16. Coronavirus and the labor market. (2020). Retrieved from https://innpoland.pl/159181,koronawirus-arynek-pracy. (in Polish)

17. March lavina of release "Anti-crisis shields" (2020). Retrieved from https://pracodawcyrp.pl/aktualnoscikoronawirus/marcowa-lawina-zwolnien-zmiotla-tarcze-antykryzysowe. (in Polish)

\section{Анна Станкевич-Мруз \\ кандидат економічних наук, доцент Лодзький технічний університет вул. Жеромського, 116, м. Лодзь, 90-924, Польща E-mail: anna.stankiewicz-mroz@p.lodz.pl, ORCID: https://orcid.org/0000-0003-4778-6672 \\ Наталія Яромінек студентка \\ Лодзький технічний університет вул. Жеромського, 116, м. Лодзь, 90-924, Польща E-mail:224953@edu.p.lodz.pl}

\section{ЗАЙНЯТІСТЬ ПОЛЬСЬКИХ СТУДЕНТІВ ПІД ЧАС ПАНДЕМІЇ COVID-19}

Стрімко зростаюча вартість життя у Польщі відбивається на високій професійній активності студентів. В даний час більшість студентів на польському ринку праці працевлаштовуються на підставі цивільно-правових угод. Цивільні угоди не гарантують відчуття безпеки і є привабливими в першу чергу для роботодавців. Цивільний договір дозволяє роботодавцям знизити витрати на працевлаштування. Привабливість подібних договорів для співробітників пов'язана з гнучкістю робочого часу. Перевага для студентів, які виконують роботу за цивільними договорами, полягає в тому, що це дозволяє їм поєднувати навчання з роботою. Але вони вважають за краще працювати неповний робочий день. Цивільні контракти часто зневажливо називають «сміттєвими контрактами», тому що вони не захищають інтереси працівника. Це стає особливо помітно під час кризи (як, наприклад, в нинішній ситуації, пов'язаної з пандемією COVID- 
19). Метою даної роботи $€$ представлення результатів аналізу становища працюючих студентів i можливості впливу цього явища на антикризові заходи, що робляться урядом з метою захисту суспільства від наслідків пандемії. Дослідження було проведено серед студентів Лодзинської Політехніки (Польща) в першому кварталі 2020 року з використанням онлайн опитування. У дослідженні допускалося, що перевага роботодавців щодо працевлаштування студентів на основі нетипових форм призводить до відсутності захисту в нових і непередбачуваних обставинах, таких як дана кризова ситуація. Стаття визначає рівень знань студентів про доступні формах допомоги в рамках Антикризового щита 2.0. Дослідження показує, що далеко не всі респонденти знають про доступну допомогу, гарантовану Законом.

Ключові слова: нетипові форми зайнятості, професійна діяльність студентів, Антикризовий щит 2.0. JEL Classification:E24, J01, J21, J62.

Анна Станкевич-Мруз

кандидат экономических наук, доцент Лодзинский технический университет ул. Жеромского, 116, г. Лодзь, 90-924, Польша E-mail: anna.stankiewicz-mroz@p.lodz.pl, ORCID: https://orcid.org/0000-0003-4778-6672

Наталья Яроминек студентка

Лодзинский технический университет ул. Жеромского, 116, г. Лодзь, 90-924, Польша E-mail: 224953@edu.p.lodz.pl

\section{ЗАНЯТОСТЬ ПОЛЬСКИХ СТУДЕНТОВ ВО ВРЕМЯ ПАНДЕМИИ COVID-19}

Стремительно растущая стоимость жизни в Польше отражается на высокой профессиональной активности студентов. В настоящее время большинство студентов на польском рынке труда трудоустраиваются на основании гражданско-правовых соглашений. Гражданские соглашения не гарантируют ощущения безопасности и являются привлекательными в первую очередь для работодателей. Гражданский договор позволяет работодателям снизить затраты на трудоустройство. Привлекательность подобных договоров для сотрудников связана с гибкостью рабочего времени. Преимущество для студентов, выполняющих работу по гражданским договорам, заключается в том, что это позволяет им совмещать учебу с работой. Но они предпочитают работать неполный рабочий день. Гражданские контракты часто пренебрежительно называют «мусорными контрактами», потому что они не защищают интересы работника. Это становится особенно заметно во время кризиса (как, например, в нынешней ситуации, связанной с пандемией COVID-19). Целью данной работы является представление результатов анализа положения работающих студентов и возможности влияния связи этого явления с антикризисными мерами, предпринимаемыми правительством с целью защиты общества от последствий пандемии. Исследование было проведено среди студентов Лодзинской Политехники (Польша) в первом квартале 2020 года с использованием онлайн опроса. В исследовании допускалось, что предпочтение работодателей в отношении занятости студентов на основе нетипичных форм приводит к отсутствию защиты в новых и непредсказуемых обстоятельствах, таких как данная кризисная ситуация. Статья определяет уровень знаний студентов о доступных формах помощи в рамках Антикризисного щита 2.0. Исследование показывает, что очень немногие респонденты знают о доступной помощи, гарантированной Законом.

Ключевые слова: нетипичные формы занятости, профессиональная деятельность студентов, Антикризисный щит 2.0.

JEL Classification:E24, J01, J21, J62. 